\title{
Diagnosis, Therapy and Follow-up of Vaginal Cancer and Its Precursors. Guideline of the DGGG and the DKG (S2k-Level, AWMF Registry No. 032/042, October 2018)
}

\section{Diagnostik, Therapie und Nachsorge des Vaginalkarzinoms und seiner Vorstufen. Leitlinie der DGGG und der DKG (S2k-Level, AWMF Registry No. 032/042, Oktober 2018)}

Authors

Hans-Georg Schnürch ${ }^{1}$, Sven Ackermann ${ }^{2}$, Celine D. Alt-Radtke ${ }^{3}$, Lukas Angleitner ${ }^{4}$, Jana Barinoff ${ }^{5}$, Matthias W. Beckmann ${ }^{6}$, Carsten Böing ${ }^{7}$, Christian Dannecker ${ }^{8}$, Tanja Fehm ${ }^{9}$, Rüdiger Gaase ${ }^{10}$, Paul Gass ${ }^{6}$, Marion Gebhardt ${ }^{11}$, Friederike Gieseking ${ }^{12}$, Andreas Günthert ${ }^{13}$, Carolin C. Hack ${ }^{6}$, Peer Hantschmann ${ }^{14}$, Lars Christian Horn ${ }^{15}$, Martin C. Koch ${ }^{6}$, Anne Letsch ${ }^{16}$, Peter Mallmann ${ }^{17}$, Bernhard Mangold ${ }^{18}$, Simone Marnitz ${ }^{19}$, Grit Mehlhorn ${ }^{20}$, Kerstin Paradies ${ }^{21}$, Michael J. Reinhardt ${ }^{22}$, Reina Tholen ${ }^{23}$, Uwe Torsten ${ }^{24}$, Wolfgang Weikel ${ }^{25}$, Linn Wölber ${ }^{26}$, Monika Hampl ${ }^{9}$

\section{Affiliations}

1 Ehem. Frauenklinik Lukaskrankenhaus, Neuss, Germany

2 Frauenklinik, Klinikum Darmstadt, Darmstadt, Germany

3 Institut für Diagnostische und Interventionelle Radiologie, Universität Düsseldorf, Düsseldorf, Germany

4 Frauenklinik, Kepler-Universitätsklinikum Linz, Linz, Austria

5 St.-Gertrauden-Krankenhaus GmbH Berlin, Berlin, Germany

6 Frauenklinik, Universitätsklinikum Erlangen, FriedrichAlexander-Universität Erlangen-Nürnberg; Comprehensive Cancer Center (CCC) Erlangen-EMN, Erlangen, Germany

7 Katholisches Klinikum Oberhausen, Frauenklinik St. Clemens-Hospital, Oberhausen, Germany

8 Klinik und Poliklinik für Frauenheilkunde und Geburtshilfe, Universität München, Campus Großhadern, München, Germany

9 Klinik für Frauenheilkunde und Geburtshilfe, Universität Düsseldorf, Düsseldorf, Germany

10 Gemeinschaftspraxis für Frauenheilkunde Gaase+Hugger, Worms, Germany

11 Frauenselbsthilfe nach Krebs, Erlangen, Germany

12 Dysplasiesprechstunde/Gynäkologisches Laserzentrum in der Frauenarztpraxis Heussweg, Hamburg, Germany

13 Gyn-Zentrum für Frauengesundheit, Luzern, Switzerland

14 Abteilung Gynäkologie und Geburtshilfe, Kreiskliniken Altötting - Burghausen, Altötting, Germany

15 Institut für Pathologie, Universitätsklinikums Leipzig, Leipzig, Germany

16 Medizinische Klinik mit Schwerpunkt Hämatologie und Onkologie, Charité Berlin, Berlin, Germany

17 Klinik und Poliklinik für Frauenheilkunde und Geburtshilfe, Universität Köln, Köln, Germany
18 Zyto-Labor Ludwigsburg, Ludwigsburg, Germany

19 Klinik für Radioonkologie, CyberKnife- und Strahlentherapie, Uniklinik Köln, Köln, Germany

20 Frauenarztpraxis Erlangen, Erlangen, Germany

21 Konferenz Onkologischer Kranken- und Kinderkrankenpflege, Berlin, Germany

22 Klinik für Nuklearmedizin, Pius-Hospital Oldenburg, Oldenburg, Germany

23 Deutscher Verband für Physiotherapie, Köln, Germany

24 Klinik für Gynäkologie und Zentrum für Beckenbodenerkrankungen, Vivantes Klinikum Neukölln, Berlin, Germany

25 Klinik für Gynäkologie und gynäkologische Onkologie, Universitätsfrauenklinik Mainz, Mainz, Germany

26 Klinik und Poliklinik für Gynäkologie, Universitätsklinikum Hamburg-Eppendorf, Hamburg, Germany

Key words

vaginal cancer, VaIN, sentinel lymph node biopsy

Schlüsselwörter

Vaginalkarzinom, VaIN, Sentinel-Biopsie

received $\quad 13.5 .2019$

accepted 13.5.2019

Bibliography

DOI https://doi.org/10.1055/a-0919-4959

Published online 16.7.2019 | Geburtsh Frauenheilk 2019; 79: 1060-1078 @ Georg Thieme Verlag KG Stuttgart · New York I ISSN 0016-5751 
Correspondence

Prof. Dr. Hans-Georg Schnürch

Im Hunengraben 9, 41564 Kaarst, Germany

hgschnuerch@gmail.com

\section{ABSTRACT}

Purpose This is an official guideline, published and coordinated by the Gynecological Oncology Working Group (AGO) of the German Cancer Society (DKG) and the German Society for Gynecology and Obstetrics (DGGG). Vaginal cancers are rare tumors, which is why there is very little evidence on these tumors. Knowledge about the optimal clinical management is limited. This first German S2k guideline on vaginal cancer has aimed to compile the most current expert knowledge and offer new recommendations on the appropriate treatment as well as providing pointers about individually adapted therapies with lower morbidity rates than were previously generally available. The purpose of this guideline is also to set up a register to record data on treatment data and the course of disease as a means of obtaining evidence in future.

Methods The present S2k guideline was developed by members of the Vulvar und Vaginal Tumors Commission of the AGO in an independently moderated, structured, formal consensus process and the contents were agreed with the mandate holders of the participating scientific societies and organizations.

Recommendations To optimize the daily care of patients with vaginal cancer: 1 . Monitor the spread pattern; 2 . Follow the step-by-step diagnostic workup based on initial stage at detection; 3. As part of individualized clinical therapeutic management of vaginal cancer, follow the sentinel lymph node protocol described here, where possible; 4. Participate in the register study on vaginal cancer.

\section{ZUSAMMENFASSUNG}

Ziel Offizielle Leitlinie, publiziert und koordiniert von der Arbeitsgemeinschaft Gynäkologische Onkologie (AGO) in der Deutschen Krebsgesellschaft (DKG) und der Deutschen Gesellschaft für Gynäkologie und Geburtshilfe (DGGG). Vaginalkarzinome gehören zu den seltenen Tumoren, dadurch fehlen bisher Evidenzen. Kenntnisse über das optimale klinische Management sind gering. Diese erste deutsche S2k-Leitlinie zum Vaginalkarzinom soll das aktuelle Expertenwissen zusammentragen und neue Behandlungsempfehlungen anbieten, um eine individuell angepasste Therapie mit geringerer Morbidität als bisher zu ermöglichen. Zur zukünftigen Gewinnung von Evidenzen soll eine Registerstelle für die Behandlungsdaten und Krankheitsverläufe eingerichtet werden.

Methoden Die vorliegende S2k-Leitlinie wurde von den Mitgliedern der Kommission Vulva- und Vaginaltumoren der AGO entworfen, in einem unabhängig moderierten formalen Konsensusverfahren strukturiert entwickelt und mit den Mandatsträgern der beteiligten Fachgesellschaften und Organisationen abgestimmt.

Empfehlungen Für die tägliche Optimierung der Versorgung von Patientinnen mit Vaginalkarzinom gilt: 1. Beachtung des Ausbreitungsmusters. 2. Einhaltung der abgestuften Diagnostik in Abhängigkeit vom Ausgangsstadium. 3. Wenn möglich Einsatz des Sentinel-Verfahrens im Rahmen eines individualisierten klinisch-therapeutischen Managements der Vaginalkarzinome. 4. Teilnahme an der Registerstudie zum Vaginalkarzinom.

\section{Guideline Information}

\section{Guidelines program of the DGGG, OEGGG and SGGG}

For information on the guidelines program, please refer to the end of the guideline.

\section{Citation format}

Diagnosis, Therapy and Follow-up of Vaginal Cancer and Its Precursors. Guideline of the DGGG and the DKG (S2k-Level, AWMF Registry No.032/042, October 2018). Geburtsh Frauenheilk 2019; 79: 1060-1078

\section{Guideline documents}

The complete long version in German, the short version and a German-language PDF slide version for PowerPoint presentations are available on the homepage of the AWMF: https://www.awmf. org/leitlinien/detail/II/032-042.html

\section{Numbering}

This text version of the guideline is a concise abridged version which has omitted generally applicable chapters (12 Supportive Therapy, 13 Psycho-oncology and Quality of Life, 14 Rehabilitation, 15 Integrative Medicine, 18 Palliative Medical Support). The numbering of the chapters after "IV Guideline" and the numbering of the recommendations and statements in this short version corresponds to the numbering used in the long version, despite the obvious gaps in numbering. This was done to make it easier to find the text in the long version if further information is desired.

\section{Guideline group}

The members of the guideline group are listed under "Authors". The group is composed of authors and mandate holders. The latter are representatives of the medical societies, working groups, organizations, and associations who stated their interest in being involved in the compilation of the guideline text and participated in the consensus conference. The authors and mandate holders and their functions are listed in $>$ Table 1. 
\ Table 1 Guideline authors and mandate holders (listed alphabetically).

\begin{tabular}{|c|c|c|}
\hline Author, mandate holder & Function* & Group, body \\
\hline Ackermann, PD Dr. med. Sven & A & $\begin{array}{l}\text { German Society of Gynecology and Obstetrics [Deutsche Gesellschaft für Gynäkologie und } \\
\text { Geburtshilfe] (DGGG), German Cancer Society [Deutsche Krebsgesellschaft] (DKG), } \\
\text { Gynecological Oncology Working Group [Arbeitsgemeinschaft Gynäkologische Onkologie] (AGO) }\end{array}$ \\
\hline Alt-Radtke, Dr. med. Celine Desirée & $A, M$ & $\begin{array}{l}\text { German Roentgen Society [Deutsche Röntgengesellschaft] (DRG), } \\
\text { Uroradiology Working Group [AG Uroradiologie] }\end{array}$ \\
\hline Angleitner, Prof. Dr. Lukas & M & $\begin{array}{l}\text { Austrian Society of Gynecology and Obstetrics } \\
\text { [Österreichische Gesellschaft für Gynäkologie und Geburtshilfe] (OEGGG) }\end{array}$ \\
\hline Barinoff, Dr. med. Jana & A & DGGG, DKG, AGO \\
\hline Beckmann, Prof. Dr. med. Matthias W. & A & $\begin{array}{l}\text { DGGG, DKG, German Cancer Aid [Deutsche Krebshilfe] (DKH), } \\
\text { German Society for Senology [Deutsche Gesellschaft für Senologie] (DGS), } \\
\text { AGO, Comprehensive Cancer Center Erlangen EMN (CCC ER-EMN) }\end{array}$ \\
\hline Böing, Dr. med. Carsten & A & DGGG, DKG, AGO \\
\hline Dannecker, Prof. Dr. med. Christian & A & DGGG, DKG, AGO \\
\hline Fehm, Prof. Dr. med. Tanja & M & AGO Executive Board \\
\hline Gaase, Dr. med. Rüdiger & M & Professional Association of Gynecologists [Berufsverband der Frauenärzte e. V.] (BVF) \\
\hline Gaß, Dr. med. Paul & A & DGGG-Leitliniensekretariat \\
\hline Gebhardt, Marion & M & $\begin{array}{l}\text { Federal Association of Women's Self-help Groups After Cancer } \\
\text { [Bundesverband Frauenselbsthilfe nach Krebs e.V.] (FSH) }\end{array}$ \\
\hline Gieseking, Dr. med. Friederike & $A, M$ & $\begin{array}{l}\text { DGGG, DKG, AGO, Cervical Pathology and Colposcopy Working Group } \\
\text { [AG Cervix-Pathologie und Colposcopie] (AGCPC) }\end{array}$ \\
\hline Günthert, Prof. Dr. med. Andreas & A & DGGG, DKG, AGO \\
\hline Hack, PD Dr. med. Caroline C. & $A, M$ & DGGG, DKG, AGO \\
\hline Hampl, Prof. Dr. med. Monika & $\mathrm{A}, \mathrm{M}$ & DGGG, DKG, AGO \\
\hline Hantschmann, Dr. med. Peer & A & DGGG, DKG, AGO \\
\hline Horn, Prof. Dr. med. Lars Christian & $A, M$ & German Society of Pathology [Deutsche Gesellschaft für Pathologie] (DGP), DKG, AGO \\
\hline Koch, Dr. med. Martin C. & A & DGGG, DKG, AGO \\
\hline Letsch, Dr. med. Anne & $A, M$ & $\begin{array}{l}\text { German Society for Hematology and Medical Oncology [Deutsche Gesellschaft } \\
\text { für Hämatologie und medizinische Onkologie] (DGHO), German Society for Palliative Medicine } \\
\text { [Deutsche Gesellschaft für Palliativmedizin] (DGPm) }\end{array}$ \\
\hline Mallmann, Prof. Dr. med. Peter & $\mathrm{A}, \mathrm{M}$ & DGGG, DKG, AGO \\
\hline Mangold, Dr. med. Bernhard & $A, M$ & German Society for Cytology [Deutsche Gesellschaft für Zytologie] (DGZ) \\
\hline Marnitz, Prof. Dr. med. Simone & $\mathrm{A}, \mathrm{M}$ & $\begin{array}{l}\text { German Society for Radio-oncology [Deutsche Gesellschaft für Radioonkologie] (DEGRO), } \\
\text { DKG, AGO }\end{array}$ \\
\hline Mehlhorn, PD Dr. med. Grit & A & DGGG, DKG, AGO \\
\hline Paradies, Kerstin & M & $\begin{array}{l}\text { Conference for Oncological Nursing Care and Nursing Care of Children } \\
\text { [Konferenz onkologischer Kranken- und Kinderkrankenpflege e.V.] (KOK) }\end{array}$ \\
\hline Reinhardt, Prof. Dr. med. Michael J. & M & German Society of Nuclear Medicine [Deutsche Gesellschaft für Nuklearmedizin e. V.] (DGN) \\
\hline Schnürch, Prof. Dr. med. Hans-Georg & $A, M$ & DGGG, DKG, AGO \\
\hline Tholen, Reina & M & German Association for Physiotherapy [Deutscher Verband für Physiotherapie] \\
\hline Torsten, PD Dr. med. Uwe & A & DGGG, DKG, AGO \\
\hline Weikel, Prof. Dr. med. Wolfgang & A & DGGG, DKG, AGO \\
\hline Wetzig, PD Dr. med. Tino & M & German Dermatological Society [Deutsche Dermatologische Gesellschaft] (DDG) \\
\hline Wölber, Prof. Dr. med. Linn & A & DGGG, DKG, AGO \\
\hline Zraik, Dr. med. Isabella & M & German Society for Urology [Deutsche Gesellschaft für Urologie] (DGU) \\
\hline
\end{tabular}

Dr. M. Nothacker (an AWMF-certified guidelines advisor/moderator) kindly agreed to moderate the guideline. Dr. P. Gaß (DGGG Guidelines Office, Erlangen) contributed substantially to the compilation of the long and short versions of this guideline. 


\begin{tabular}{|c|c|c|c|}
\hline \multicolumn{2}{|c|}{ Abbreviations } & \multirow{2}{*}{$\begin{array}{l}\text { SLN } \\
\text { SLNB }\end{array}$} & \multirow{2}{*}{$\begin{array}{l}\text { sentinel lymph node } \\
\text { sentinel lymph node biopsy }\end{array}$} \\
\hline AG & working group [Arbeitsgemeinschaft] & & \\
\hline \multirow[t]{3}{*}{ AG-CPC } & Cervical Pathology and Colposcopy Working Group & SPECT & single-photon emission computed tomography \\
\hline & [Arbeitsgemeinschaft für Cervixpathologie und & TNM system & tumor-node-metastasis staging system \\
\hline & Colposkopie] & UICC & Union internationale contre le cancer \\
\hline \multirow[t]{2}{*}{ AGO } & Gynecological Oncology Working Group & ValN & vaginal intraepithelial neoplasia \\
\hline & [Arbeitsgemeinschaft Gynäkologische Onkologie] & VIN & vulvar intraepithelial neoplasia \\
\hline \multirow[t]{3}{*}{ AWMF } & Association of the Scientific Medical Societies in & V status & vessel status \\
\hline & Germany [Arbeitsgemeinschaft der Wissenschaft- & WHO & World Health Organization \\
\hline & lichen Medizinischen Fachgesellschaften] & WLE & wide local excision \\
\hline AM & complementary and alternative medicine & & \\
\hline $\mathrm{CCC}$ & comprehensive cancer center & II & idoling Angliratinn \\
\hline 4 & cervical intraepithelial neoplasia & & \\
\hline
\end{tabular}

CT computed tomography

DHCD data-sparing homogeneous cancer documentation

DGGG German Society of Gynecology and Obstetrics

[Deutsche Gesellschaft für Gynäkologie und

Geburtshilfe]

DKG German Cancer Society

[Deutsche Krebsgesellschaft]

EORTC European Organisation for Research and Treatment of Cancer

FDG-PET fluorodeoxyglucose-positron emission tomography

FIGO Fédération Internationale de Gynécologie et

d'Obstétrique

$\mathrm{H} \& \mathrm{E} \quad$ hematoxylin and eosin

HPV human papillomaviruses

HSIL high-grade squamous intraepithelial lesion

LDA lymph drainage area

LN lymph node

LNE lymph node excision

LN status lymph node status

LSIL low grade squamous intraepithelial lesion

MRI magnetic resonance imaging

NCCAM National Center of Complementary and Alternative Medicine

NCDB National Cancer Data Base

OEGGG Austrian Society of Gynecology and Obstetrics

[Österreichische Gesellschaft für Gynäkologie und Geburtshilfe]

OL Oncology Guidelines Program

[Leitlinienprogramm Onkologie]

$\mathrm{PE} \quad$ biopsy [Probe-Exzision]

PET positron emission tomography

PNI status perineural invasion status

QI quality indicator

QLQ quality of life questionnaire

R1 microscopic residual disease

R2 macroscopic residual disease

RCTX radio(chemo)therapy

SGB (German) Social Security Statute Book

[Sozialgesetzbuch]

SGGG Swiss Society of Gynecology and Obstetrics

[Schweizerische Gesellschaft für Gynäkologie

und Geburtshilfe]

\section{Purpose and objectives}

Although vaginal cancer is a rare tumor entity, there is no summary of recent experience or list of appropriate recommendations for the medical staff treating these rare cases. This guideline completes the range of gynecological oncology guidelines of the DGGG and DKG. As radiotherapy also plays an important role in the treatment of vaginal cancer, the interdisciplinary compilation of this guideline ensures that all treatment modalities - surgery, radiotherapy and systemic therapy - were given appropriate consideration. This guideline aims to make the specialist knowledge about the diagnosis and treatment of vaginal cancer available to all treatment teams in the form of recommendations, statements and explanatory text.

\section{Targeted areas of patient care}

The guideline covers the full spectrum of diagnosis, treatment and follow-up of patients with vaginal cancer, including patients with microinvasive lesions and high-grade precursors. This guideline's area of application is cross-sectional and includes both outpatient and inpatient care. All relevant scientific medical societies, selfhelp groups and professional associations in Germany were therefore involved in the compilation of this guideline.

\section{Target user groups/target audience}

This $52 \mathrm{k}$ guideline is aimed at all physicians and healthcare professionals involved in the outpatient and/or inpatient care of patients with vaginal cancer. This guideline also aims to serve as an important source of information for affected patients and their relatives.

\section{Adoption and period of validity}

The validity of this guideline was confirmed by the executive boards of the participating medical societies, working groups, organizations and associations as well as by the executive board of the DGGG, the DGGG guidelines commission and the DKG in October 2018 and was thus confirmed in its entirety. This guideline is valid from 1 October 2018 through to 30 September 2023. Because of the contents of this guideline, this period of validity is only an estimate. 


\section{Method}

The method used to prepare this guideline was determined by the class to which this guideline was assigned. The AWMF Guidance Manual (version 1.0) has set out the respective rules and requirements for different classes of guidelines. Guidelines are differentiated into lowest (S1), intermediate (S2) and highest (S3) class. The lowest class is defined as a set of recommendations for action compiled by a non-representative group of experts. In 2004, the S2 class was divided into two subclasses: a systematic evidencebased subclass (S2e) and a structural consensus-based subclass (S2k). The highest $\mathrm{S} 3$ class combines both approaches.

This guideline is classified as: $\mathbf{S 2} \mathbf{k}$

\section{Grading of recommendations}

The grading of evidence and of recommendations is not envisaged for S2k-level guidelines. The individual Statements and Recommendations are differentiated by syntax, not by symbols ( $>$ Table 2).

- Table 2 Grading of recommendations.

\begin{tabular}{|l|l|}
\hline Level of recommendation & Syntax \\
\hline Strong recommendation, highly binding & must/must not \\
\hline Simple recommendation, moderately binding & should/should not \\
\hline Open recommendation, not binding & may/may not \\
\hline
\end{tabular}

\section{Statements}

Scientific statements given in this guideline which do not consist of any direct recommendations for action but are simple statements of fact are referred to as "Statements". It is not possible to provide any information about the grading of evidence for these Statements.

\section{Achieving consensus and strength of consensus}

As part of the structured process to achieve consensus (S2k/S3 level), authorized participants attending the consensus conference vote on draft Statements and Recommendations. This can lead to significant changes in the wording, etc. Finally, the extent of consensus is determined based on the number of participants who voted and the number of participants who voted in favor ( Table 3).

\begin{tabular}{|c|c|c|}
\hline Symbol & Strength of consensus & Extent of agreement in percent \\
\hline+++ & Strong consensus & $>95 \%$ of participants agree \\
\hline++ & Consensus & $>75-95 \%$ of participants agree \\
\hline+ & Majority agreement & $>50-75 \%$ of participants agree \\
\hline- & No consensus & $<51 \%$ of participants agree \\
\hline
\end{tabular}

\section{Expert consensus}

As the name already implies, this term refers particularly to consensus decisions on Recommendations/Statements where the decision was taken without a prior systematic search of the literature (S2k) or for which evidence is lacking (S2e/S3). The term "expert consensus" (EC) used here is synonymous with terms used in other guidelines such as "good clinical practice" (GCP) or "clinical consensus point" (CCP). The strength of the recommendation is graded as previously described in the chapter "Grading of recommendations", i.e., purely semantically ("must”|“must not” or "should"|"should not" or "may"|"may not") without the use of symbols.

\section{Quality indicator}

The QI working group of the Vulva and Vagina Commission has proposed that histological confirmation of the primary vaginal cancer prior to planning therapy in a tumor conference should be the only quality indicator for this rare entity.

\section{Guideline}

\section{Epidemiology}

Vaginal cancer is a rare tumor with only around 500 new cases reported annually in Germany [1]. The majority of all invasive vaginal cancers are squamous cell carcinomas (>95\%), followed by adenocarcinomas ( $<5 \%$ ) and melanomas (<1\%) [2]. The majority of clear cell adenocarcinomas are associated with maternal intake of the drug diethylstilbestrol (DES) during pregnancy [3]. Vaginal metastasis and recurrence and vaginal infiltration caused by direct expansion of an adjacent malignancy of the cervix, vulva, endometrium or rectum are more common than primary vaginal cancer, and primary vaginal carcinoma must be differentiated from all of these entities.

\subsection{Age distribution}

In more than $50 \%$ of cases, the age at onset of primary vaginal cancer is 70 years and above. Only $15 \%$ of these carcinomas are diagnosed in patients between the ages of 20 and 49 years [4].

\subsection{Survival rate}

The absolute 5 -year survival rate correlates with the histological subtype: it is $54 \%$ for squamous cell carcinoma, $60 \%$ for adenocarcinoma, and $13 \%$ for patients with malignant melanoma [4]. The 5 -year survival rate also correlates with the tumor stage at primary diagnosis: it is $20 \%$ for stage IV.

\subsection{Risk factors}

\section{Consensus-based Statement 1.S1}

\begin{tabular}{l|l} 
Expert consensus & Strength of consensus +++
\end{tabular}

The risk factors for developing vaginal cancer are similar to those for cervical cancer. 
Consensus-based Statement 1.S2

\begin{tabular}{l|l} 
Expert consensus & Strength of consensus +++
\end{tabular}

Infection with human high-risk papillomavirus (HR-HPV) is one of the most important risk factors.
Consensus-based Statement 1.S3

\begin{tabular}{l|l} 
Expert consensus & Strength of consensus +++
\end{tabular}

Vaginal cancer has been reported to develop in up to $5 \%$ of cases with ValN. A VaIN 2-3/HSIL is a precancerous lesion.

The risk factors for developing squamous cell tumors of the vagina are the same as those for cervical cancer:

- infection with high-risk human papillomavirus

- previous treatment for preinvasive or invasive HPV-induced lesions

- multiple sexual partners

- early age at first intercourse

- smoking [5]

\subsubsection{HPV}

HPV DNA was detected in $74 \%$ of vaginal carcinomas and in $96 \%$ of ValN 2/3 lesions. HPV 16 is the most commonly detected subtype both for ValN and invasive tumors (59\%).

\subsubsection{ValN}

A vaginal intraepithelial neoplasia (VaIN) may be found sequentially or simultaneously with vaginal cancer. The precise incidence of ValN ist not clear. It is often reported as 0.2 to 0.3 cases per 100000 women and year [6]. There is a coincidence with other neoplasias of the lower anogenital tract $[7,14]$. The data show that long-term follow-up is necessary in all cases with VaIN. The rate of progression for ValN developing into vaginal carcinoma is $2-5 \%$. The same chapter in the long version of this guideline provides more details on the above data on the rate of progression.

2

\section{$2.1 \quad$ Primary prevention}

\section{Consensus-based Statement 2.54}

\begin{tabular}{l|l} 
Expert consensus & Strength of consensus +++
\end{tabular}

Because of the heterogeneity of the data, it is not possible to provide a final statement on whether targeted sexual hygiene, which is recommended for other sexually transmissible diseases, has a preventative effect on vaginal neoplasia.
Based on the distribution of HPV types, up to $60 \%$ of all vaginal carcinomas could theoretically be prevented by HPV vaccination [8]. According to the current recommendations of the STIKO, HPV vaccination is also useful with respect to the primary prevention of vaginal cancer and its precursors. As smoking increases the risk of women who test positive for HPV (high-risk types) developing a VaIN [9], women who smoke should always be provided with appropriate information in the context of preventing ValN. The long version of this chapter includes details on the role of specific protective measures.

\subsection{Screening (secondary prevention)}

\begin{tabular}{l|l|}
\hline Consensus-based Statement 2.S5 \\
\hline Expert consensus & Strength of consensus +++
\end{tabular}

The legally mandated screening program for cervical cancer offers the opportunity to diagnose vaginal cancers and their precursors at an early stage.

3.2 Treatment in oncology centers

\section{Consensus-based Recommendation 3.E1}

Expert consensus

Strength of consensus +++

Patients with vaginal cancer should be treated by an interdisciplinary, interprofessional team. The team should have access to all necessary medical specialties and occupations in a cross-sectoral network. A certified center is most likely to be able to provide this extensive access.

\subsubsection{Centers - interdisciplinary tumor board}

Consensus-based Recommendation 3.E2

Expert consensus Strength of consensus +++

All patients with vaginal cancer must be presented to an interdisciplinary tumor board. 


\section{$4 \quad$ Pathology}

\subsection{Classification of precancerous lesions ( $\bullet$ Table 4 )}

- Table 4 Nomenclature of HPV-associated precancerous vaginal lesions [10-12].

\begin{tabular}{|c|c|c|c|c|c|}
\hline Description & Condylomatous lesion & Low-grade dysplasia & Intermediate-grade dysplasia & High-grade dysplasia & Carcinoma in situ \\
\hline WHO (2003) & \multicolumn{2}{|l|}{ ValN 1} & ValN 2 & \multicolumn{2}{|l|}{ ValN 3} \\
\hline LAST project* & \multicolumn{2}{|c|}{ Low-grade squamous intraepithelial lesion (LSIL) } & \multicolumn{3}{|c|}{ High-grade squamous intraepithelial lesion (HSIL) } \\
\hline WHO (2014) & \multicolumn{2}{|c|}{$\begin{array}{l}\text { Low-grade squamous intraepithelial lesion (LSIL) } \\
\text { syn.: VaIN } 1\end{array}$} & \multicolumn{3}{|c|}{$\begin{array}{l}\text { High-grade squamous intraepithelial lesion (HSIL) } \\
\text { syn.: VaIN } 2 \text { and VaIN } 3\end{array}$} \\
\hline
\end{tabular}

* LAST = Lower Anogenital Squamous Terminology Standardization project of the College of American Pathologists and the American Society of Colposcopy and Cervical Pathology [13].

\section{Consensus-based Recommendation 4.E3}

\begin{tabular}{|l|l|}
\hline Expert consensus & Strength of consensus +++ \\
\hline
\end{tabular}

The clinical terminology and morphological workup of a precancerous vaginal lesion (vaginal intraepithelial neoplasia; VaIN) must be based on the most recent valid version of the WHO classification.

In addition to its classification as LSIL or HSIL, HPV-associated changes (e.g. condylomas) should be specified and the lesion should be graded (ValN 1 to 3 ).

\subsection{Vaginal Paget's disease}

\section{Consensus-based Recommendation 4.E4}

\section{Expert consensus}

\section{Strength of consensus +++}

If histological examination detects pagetoid changes in a vaginal biopsy specimen, locoregional cancer and vulvar Paget's disease with vaginal involvement must be clinically excluded.

$$
\text { Morphology of malignant vaginal tumors }
$$

\subsubsection{Tumor typing}

\section{Consensus-based Recommendation 4.E5}

\section{Expert consensus}

Strength of consensus +++

The histological classification of malignant vaginal tumors must be based on the most current version of the WHO classification.

\subsubsection{Staging of vaginal carcinoma}

Postoperative staging is done using the PTNM classification system [14]; citing the FIGO stage [15] is optional (s. Chapter 5.7).

From a morphological standpoint, the WHO definition of vaginal cancer is problematic. According to this definition, squamous cell cancer of the vagina is defined as a vaginal carcinoma without a previous cervical or vulvar carcinoma in the 10 years before the current diagnosis $[11,16,17]$. Otherwise the vaginal cancer is considered to be a recurrence of a previously treated carcinoma. Equally problematic is the statement by FIGO that squamous cell cancer of the vagina with involvement of the cervix should be classified as a cervical carcinoma [17].

As with cervical and vulvar carcinomas, the depth of invasion should be defined as the extent of stromal invasion measured from the epithelial-stromal border at the most superficial dermal papilla adjacent to invasion to the deepest point of invasion [13, $14,18]$. Lymph node infiltration which extends beyond the deepest point of invasion must not be included in the measured depth of invasion or the tumor thickness but must be classified as L1 [13, $14,18]$. Tumor thickness is measured from the surface of the tumor or, in the case of (strongly) keratinized squamous cell carcinomas, from the granular cell layer to the deepest point of invasion $[13,19]$.

\subsubsection{Evaluation of tissue specimens}

\section{Consensus-based Recommendation 4.E6}

\begin{tabular}{|l|l|}
\hline Expert consensus & Strength of consensus +++
\end{tabular}

Biopsy specimens obtained from areas suspicious for ValN must be processed and sliced into sections for further evaluation.

\subsubsection{Diagnostic biopsies}

\section{Consensus-based Recommendation 4.E7}

Expert consensus Strength of consensus +++

The biopsy findings report must provide information about the confirmation and type of VaIN, the presence of any dermatological disease, any virus-associated changes, and possible invasion. 


\subsubsection{Specimens after local excision, colpectomy, hysterocolpectomy and lymph node status}

\section{Consensus-based Recommendation 4.E8 \\ Expert consensus \\ Strength of consensus +++ \\ Morphological processing of colpectomy specimens in vaginal cancer must be carried out in such a way that all therapeutic and prognostically relevant parameters can be evaluated. The findings report must use the most recent valid WHO classification of tumor types and the most current TNM classifi- cation for staging.}

\section{Consensus-based Recommendation 4.E9}

\section{Expert consensus}

Strength of consensus +++

The report detailing the histological findings of (radical) colpectomy specimens resected for vaginal cancer must include the following information:

- histological type using the WHO classification

- grading

- proof/absence of lymph node or vascular invasion (LN und V status)

- proof/absence of perineural infiltration (PNI status)

- staging (PTNM)

- depth of invasion in mm

- three-dimensional tumor size in $\mathrm{cm}$

- minimum metric distance between the carcinoma and any associated ValN measured from the edge of the resection to the ValN

- minimum metric distance between the tumor and the soft-tissue edge of the resection (paracolpic tissue)

- R classification (UICC)

\section{Consensus-based Recommendation 4.E10}

Expert consensus Strength of consensus +++

All resected lymph nodes obtained by lymphadenectomy during the surgical treatment of vaginal cancer must be examined histologically.

\section{Consensus-based Recommendation 4.E11}

\section{Expert consensus}

\section{Strength of consensus +++}

Lymph nodes up to a diameter of approx. $0.3 \mathrm{~cm}$ should be entirely embedded; larger lymph nodes should be cut in half along their longitudinal axis and also completely embedded.

According to the UICC and TNM classification systems, micrometastasis is defined as the histological confirmation of tumor cells measuring $\geq 0.2 \mathrm{~mm}$ and no larger than $0.2 \mathrm{~cm}$ in lymph nodes $[20,21]$. Tumor cells with a total length of $<0.2 \mathrm{~mm}$ are defined as isolated tumor cells in lymph nodes $[20,21]$. The detection of isolated tumor cells and evidence of micrometastasis are not relevant for the staging of vaginal cancer.

\section{Consensus-based Recommendation 4.E12}

\section{Expert consensus}

\section{Strength of consensus +++}

The report on the findings for lymphadenectomy specimens resected for vaginal cancer must include the following information:

- The number of affected lymph nodes compared to the number of resected lymph nodes together with information on the biopsy location and side (pelvic, poss. inguinofemoral)

- The size of the largest lymph node metastasis in mm

- Information whether lymph node metastasis has spread beyond the capsule or not

- Information on the presence/absence of isolated tumor cells in the lymph node, in lymphatic vessels in perinodal adipose tissue, and/or in the lymph node capsule

\subsubsection{Sentinel lymph nodes}

\section{Consensus-based Recommendation 4.E13}

\section{Expert consensus}

\section{Strength of consensus +++}

In cases with vaginal cancer, the sentinel lymph nodes must be completely embedded and cut into slides for examination. Sentinel lymph nodes which are found to be negative based on an examination of their morphology using $\mathrm{H} \& \mathrm{E}$ staining, must additionally be investigated by immunohistochemistry (ultrastaging).

\subsubsection{Morphological prognostic factors}

The prognostic contribution of individual morphological tumor characteristics is summarized in $>$ Table 5.

- Table 5 Prognostic factors for vaginal cancer.

\begin{tabular}{|c|c|c|c|}
\hline Name & $\begin{array}{l}\text { Stan- } \\
\text { dard } \\
\text { factor }\end{array}$ & $\begin{array}{l}\text { Risk/ } \\
\text { prognos- } \\
\text { tic factor }\end{array}$ & $\begin{array}{l}\text { Relevant } \\
\text { for treat- } \\
\text { ment }\end{array}$ \\
\hline Tumor stage & Yes & Yes & Yes \\
\hline Lymph node status & Yes & Yes & Yes \\
\hline $\begin{array}{l}\text { Size of respective lymph node } \\
\text { metastasis }\end{array}$ & Yes & Unclear & Yes \\
\hline $\begin{array}{l}\text { Number of inguinal lymph nodes } \\
\text { with metastatic disease }\end{array}$ & Yes & Unclear & Yes \\
\hline $\begin{array}{l}\text { Extracapsular extension of } \\
\text { inguinal lymph node metastasis }\end{array}$ & Yes & Unclear & Yes \\
\hline Perineural infiltration (PNI status) & Yes & Unclear & No \\
\hline $\begin{array}{l}\text { Lymph node infiltration } \\
\text { (LN status) }\end{array}$ & Yes & Unclear & No \\
\hline Venous invasion (V status) & Yes & Unclear & No \\
\hline $\begin{array}{l}\text { Resection margins (residual } \\
\text { tumor status; R classification) }\end{array}$ & Yes & Yes & Yes \\
\hline Depth of invasion in mm & Yes & Unclear & No \\
\hline Grading & Yes & Unclear & No \\
\hline $\begin{array}{l}\text { Three-dimensional tumor size } \\
\text { in cm }\end{array}$ & Yes & Unclear & Yes \\
\hline
\end{tabular}


- Table 5 Prognostic factors for vaginal cancer. (Continued)

\begin{tabular}{|c|c|c|c|}
\hline Name & $\begin{array}{l}\text { Stan- } \\
\text { dard } \\
\text { factor }\end{array}$ & $\begin{array}{l}\text { Risk/ } \\
\text { prognos- } \\
\text { tic factor }\end{array}$ & $\begin{array}{l}\text { Relevant } \\
\text { for treat- } \\
\text { ment }\end{array}$ \\
\hline $\begin{array}{l}\text { Location of the cancer in the } \\
\text { vagina }\end{array}$ & Yes & Unclear & $\begin{array}{l}\text { Yes (poss. } \\
\text { surgical } \\
\text { approach) }\end{array}$ \\
\hline $\begin{array}{l}\text { Macroscopic type of growth } \\
\text { of the carcinoma }\end{array}$ & Yes & Unclear & No \\
\hline Multifocal carcinoma & Yes & Unclear & $\begin{array}{l}\text { Yes (surgical } \\
\text { approach) }\end{array}$ \\
\hline Peritumoral ValN & Yes & Unclear & $\begin{array}{l}\text { Yes (surgical } \\
\text { approach) }\end{array}$ \\
\hline Histological tumor type & Yes & Unclear & $\begin{array}{l}\text { No (pure } \\
\text { adeno- } \\
\text { carcinoma, } \\
\text { poss. not ra- } \\
\text { diosensitive) }\end{array}$ \\
\hline $\begin{array}{l}\text { HPV confirmation in the } \\
\text { carcinoma }\end{array}$ & No & Unclear & No \\
\hline Pattern of invasion & No & Unclear & No \\
\hline $\begin{array}{l}\text { Immunohistochemical ultrastag- } \\
\text { ing of lymph nodes for metastasis }\end{array}$ & No & Unclear & Unclear \\
\hline Molecular markers & No & Unclear & Unclear \\
\hline
\end{tabular}

\section{5}

\subsection{Clinical workup}

Consensus-based Statement 5.56

Expert consensus

Strength of consensus +++

The diagnostic workup of a suspicious vaginal lesion must consist of clinical, cytological and colposcopic examinations depending on the manifestation of the lesion. The lesion must be biopsied if the findings are suspicious.

\subsection{Histological workup}

All suspicious lesions must be examined histologically.

\subsection{Pretreatment staging of a carcinoma}

\footnotetext{
Consensus-based Recommendation 5.E14

Expert consensus

Strength of consensus +++

Prior to treatment of a confirmed carcinoma, the following examinations must be carried out:

- gynecological examination of the entire anogenital area (multicentric/ multifocal)

- determination of the location, spread and size of the tumor (colposcopy)

- assessment of the infiltration depth (palpation and poss. histological examination)

- assessment of spread to neighboring organs

- urethrocystoscopy, rectoscopy, poss. anal sonography depending on the location

- imaging examination depending on the clinical spread of the tumor
}

\subsection{Diagnostic workup of advanced tumors}

Because of the close proximity of neighboring organs and because surgical treatment often requires extensive excision to obtain healthy margins, the indications for exploration using endoscopy and imaging should be interpreted liberally.

For this reason, screening for distant metastasis in cases with large tumors must be done prior to starting treatment (see 5.6).

5.6 Imaging workup for vaginal cancer

\subsubsection{Diagnostic workup of the primary tumor}

\section{Consensus-based Statement 5.S7}

\begin{tabular}{|l|l|}
\hline Expert consensus & Strength of consensus +++
\end{tabular}

Pelvic MRI is the imaging modality of choice for the local staging of histologically confirmed vaginal carcinoma from FIGO stage II onwards.

\section{Consensus-based Recommendation 5.E15}

Expert consensus Strength of consensus +++

The current recommendations (protocol) for gynecological pelvic tumors must be followed when carrying out a functional pelvic MRI to achieve the best possible diagnostic accuracy.

Consensus-based Statement 5.58

\begin{tabular}{l|l} 
Expert consensus & Strength of consensus +++
\end{tabular}

The value of FDG-PET/CT for the staging of vaginal cancer has not been confirmed in the primary setting.

\subsubsection{Diagnostic workup of lymph nodes}

\section{Consensus-based Statement 5.59}

\begin{tabular}{|l|l|}
\hline Expert consensus & Strength of consensus +++
\end{tabular}

The amount of information which can be obtained from imaging procedures to assess pelvic lymphatic drainage in cases with primary vaginal carcinoma is higher with functional MRI than with CT or standard MRI.

\subsubsection{Distant metastasis}

Consensus-based Recommendation 5.E16

Expert consensus

Strength of consensus +++

For complete staging, a CT scan of the abdomen and chest using contrast medium should be carried out in cases with advanced vaginal carcinoma ( $\geq \mathrm{FIGO} \mathrm{II)} \mathrm{or} \mathrm{if} \mathrm{there} \mathrm{is} \mathrm{a} \mathrm{reasonable} \mathrm{suspicion} \mathrm{of} \mathrm{metastasis.}$

\section{Consensus-based Recommendation 5.E17}

\section{Expert consensus}

Strength of consensus +++

Prior to any planned pelvic exenteration, PET/CT may be used in patients with primary vaginal cancer to exclude distant metastasis insofar as this is possible. 


\subsubsection{Imaging in radiation therapy}

\section{Consensus-based Recommendation 5.E18}

Expert consensus

\section{Strength of consensus +++}

Patients who are treated with percutaneous radiotherapy, combined radiochemotherapy or brachytherapy must have an MRI scan at the start of planning treatment and to monitor therapy; where possible, the scan should be a functional MRI scan.

\subsubsection{Diagnostic workup for recurrence}

Consensus-based Recommendation 5.E19

Expert consensus

Strength of consensus +++

Patients with a suspicion of local recurrence of vaginal cancer should have a functional pelvic MRI scan to assess the extent of local spread in the pelvis.

\section{Consensus-based Recommendation 5.E20}

\section{Expert consensus}

\section{Strength of consensus +++}

Prior to planning treatment, PET/CT may be indicated in patients with a suspicion of extensive recurrence of vaginal carcinoma extending beyond the pelvic area.

\section{$5.7 \quad$ Staging}

Staging is carried out using the FIGO and TNM classification systems ( $\triangleright$ Table 6 ). The findings at surgery together with the results of the histopathological examination of the surgical specimens will determine the staging.

The pelvic lymph nodes (obturator, internal iliac, external iliac and other unspecified pelvic LNs) are the regional lymph nodes for tumors in the upper two-thirds of the vagina. The inguinofemoral LNs are the regional LNs for tumors in the lower third of the vagina.

\section{Treatment of vaginal intraepithelial neoplasia (VaIN) \\ 7.1 Local surgical therapy}

\section{Consensus-based Statement 7.S10}

\section{Expert consensus}

Strength of consensus +++

Before starting any superficial treatment for VaIN, one or more biopsies must be carried out to exclude invasive carcinoma where possible. If there is a cytological suspicion of invasion, destructive therapy must not be carried out and treatment must consist of excision instead.

- Table 6 Vaginal cancer staging according to AJCC 2017 [22]/FIGO (2018) [15]/TNM 2017 [14].

\begin{tabular}{|c|c|c|}
\hline UICC & FIGO & Tumor spread \\
\hline $\mathrm{TX}$ & & Primary tumor cannot be assessed due to lack of information \\
\hline T0 & & No evidence of a primary tumor \\
\hline Tis & 1) & Carcinoma in situ, vaginal intraepithelial neoplasia (VaIN) grade 3 \\
\hline T1a & I & Tumor is limited to the vagina and no larger than $2 \mathrm{~cm}$, it has not spread (N0, M0) \\
\hline $\mathrm{T} 1 \mathrm{~b}$ & I & Tumor is limited to the vagina and larger than $2 \mathrm{~cm}$, it has not spread (N0, M0) \\
\hline $\mathrm{T} 2 \mathrm{a}$ & II & $\begin{array}{l}\text { Tumor has infiltrated paravaginal tissue (paracolpium), is not larger than } 2 \mathrm{~cm} \text {, has not reached } \\
\text { the pelvic wall, it has not spread ( } \mathrm{N} 0, \mathrm{M} 0 \text { ) }\end{array}$ \\
\hline $\mathrm{T} 2 \mathrm{~b}$ & II & $\begin{array}{l}\text { Tumor has infiltrated paravaginal tissue (paracolpium), is larger than } 2 \mathrm{~cm} \text { but has not reached } \\
\text { the pelvic wall, it has not spread (N0, M0) }\end{array}$ \\
\hline T1 bis T3 & III & $\begin{array}{l}\text { Tumor is growing into the pelvic wall and/or the lower third of the vagina and/or blocks } \\
\text { the flow of urine, which is causing kidney problems }\end{array}$ \\
\hline N1 & & Tumor has spread into regional pelvic or inguinal LNs, no distant metastasis \\
\hline T3 & & $\begin{array}{l}\text { Tumor is growing into the pelvic wall and/or the lower third of the vagina and/or blocks the } \\
\text { flow of urine }\end{array}$ \\
\hline No & & Tumor has not spread (N0, M0) \\
\hline M0 & & \\
\hline T4 & IVA & Tumor has infiltrated the bladder mucosa and/or rectum and/or has spread beyond the pelvis²) \\
\hline Any $N$ & & \\
\hline M0 & & Tumor may or may not have spread to regional LNs, no distant metastasis \\
\hline Any $\mathrm{T}$ & IVB & Tumor has spread to distant organs (incl. pelvic LN metastasis), may or may not be infiltrating \\
\hline Any N & & adjacent structures \\
\hline M1 & & Tumor may or may not have spread to regional LNs \\
\hline
\end{tabular}


- Table 7 Treatment options for high-grade ValN depending on the location of the lesion.

\begin{tabular}{|l|l|l|l|l|}
\hline $\begin{array}{l}\text { ValN } \\
\mathbf{2 - 3} \text { (HSIL) }\end{array}$ & Lower third & Intermediate third & Vaginal vault & Entire vagina \\
\hline HPV-induced & $\begin{array}{l}\text { Excision, PE/laser vapor- } \\
\text { ization, local drug therapy }\end{array}$ & $\begin{array}{l}\text { Excision, PE/laser vapor- } \\
\text { ization, local drug therapy }\end{array}$ & $\begin{array}{l}\text { Excision, PE/laser vapor- } \\
\text { ization, upper colpectomy }\end{array}$ & $\begin{array}{l}\text { Skinning resection of vaginal epitheli- } \\
\text { um, colpectomy, local drug therapy }\end{array}$ \\
\hline HPV-negative & Excision & Excision & $\begin{array}{l}\text { Excision, upper } \\
\text { colpectomy }\end{array}$ & $\begin{array}{l}\text { Colpectomy, skinning resection of } \\
\text { vaginal epithelium }\end{array}$ \\
\hline
\end{tabular}

\section{Consensus-based Recommendation 7.E21}

\section{Expert consensus}

Strength of consensus +++

The decision which of the available guideline-based treatment options for ValN to apply must be made on an individual basis.

- Table 7 shows the optimal treatment approaches for highgrade VaIN according to their HPV status and vaginal location.

\subsection{Local drug therapy}

Local treatment may be used as an alternative to surgical treatment. This includes therapy with 5-FU or imiquimod (both are off-label uses). There are also reports of using brachytherapy.

The choice of treatment is based on the grade of the ValN lesion ( $>$ Table 8).

- Table 8 Recommendations for treatment according to ValN grade.

\section{ValN 1 (condylomatous lesion) \\ Low-grade squamous \\ intraepithelial lesion LGSIL, flat condyloma}

Regular monitoring, in exceptional cases destruction, excision, local application of imiquimod (off-label use)

\section{ValN 2-3 \\ High-grade intraepithelial neoplasia HGSIL}

Extensive PEs, followed by destruction or surgical removal (excision, skinning colpectomy, skinning excision, partial/total colpectomy) or radiotherapy

\section{3}

\section{Recurrence and progression rates}

\section{Consensus-based Recommendation 7.E22}

\section{Expert consensus}

Strength of consensus +++

Patients treated for ValN must be offered regular follow-up examinations for the rest of their lives because the rate of recurrence for ValN is high.

More information on the rates of recurrence and progression is available in the long version of the guideline.

\section{8}

\section{Surgical treatment of invasive carcinoma}

The majority of invasive vaginal cancers are treated with radio (chemo)therapy [8,23-25]. Local surgical treatment ranges from local excision to partial or total colpectomy to anterior and/or posterior exenteration [26].

\subsection{FIGO stage I}

\section{Consensus-based Statement 8.S11}

Expert consensus Strength of consensus +++

Surgery may be used to treat FIGO stage I vaginal carcinoma.

Consensus-based Recommendation 8.E23

Expert consensus

Strength of consensus +++

Circumscribed FIGO stage I tumors should be excised locally with tumorfree margins; the surgical treatment of larger tumors should consist of colpectomy or hysterectomy, if necessary.

\subsection{FIGO stage II}

\section{Consensus-based Statement 8.S12}

\begin{tabular}{l|l} 
Expert consensus & Strength of consensus +++
\end{tabular}

Radio(chemo)therapy is the standard therapy for tumor stages II to IV. Exenteration to treat stage IV vaginal carcinoma is an individual therapy decision.

\subsection{Stage III/IV}

The standard therapy consists of radio(chemo)therapy. In cases with infiltration through the wall into adjacent organs (bladder and/or rectum), anterior and/or posterior exenteration with creation of a neobladder and/or a colostomy is a surgical option which has to be decided on in the context of an individual therapy decision. 
Consensus-based Recommendation 8.E24

Expert consensus

Strength of consensus +++

Before undergoing colpectomy, the patient should be informed about the possibility of vaginal plastic reconstruction.

\section{9}

\section{Surgery of lymph drainage areas}

\subsection{Introduction}

To date, sentinel lymph node imaging has not played any significant role in the diagnosis and treatment of vaginal cancer. The lack of information about lymphatic drainage in vaginal cancer is why lymphatic imaging with sentinel node analysis is necessary. The current practice of treating all regional lymph node stations either surgically or with radiotherapy is probably overtreatment and could be reduced in individual cases with targeted imaging and biopsies of sentinel lymph nodes.

\subsection{Indication}

The issue whether to lymph node (LN) staging should be carried out in cases with vaginal carcinoma or not is a question which affects both patients for whom primary surgery is indicated and patients for whom primary radio(chemo)therapy is indicated. If surgical examination of the lymph node areas is not possible or the patient does not want it, then primary radio(chemo)therapy is indicated and should potentially also include the site of the primary tumor (see Chapter 10).

\subsection{Lymphatic drainage from the vagina}

\section{Consensus-based Statement 9.S13}

Expert consensus Strength of consensus +++

Because the correlation between tumor location and the direction of lymphatic flow is not clear due to extensive lymphatic anastomosis in the vagina and lesser pelvis, it is not possible in individual cases to clearly link the vaginal tumor site with the direction of lymphatic flow.

The literature on this issue is discussed in the long version of the guideline.

\subsection{Vaginal cancer and risk of lymphatic metastasis}

\begin{tabular}{|c|c|}
\hline \multicolumn{2}{|c|}{ Consensus-based Statement 9.S14 } \\
\hline Expert consensus & Strength of consensus +++ \\
\hline $\begin{array}{l}\text { There are no evide } \\
\text { between vaginal c } \\
\text { cancer, an infiltrat } \\
\text { risk of lymphatic n }\end{array}$ & $\begin{array}{l}\text { s which show a close correlation } \\
\text { ymphatic metastasis. As with vulvar } \\
\text { nay be an indication of an incipient }\end{array}$ \\
\hline
\end{tabular}

\subsection{Sentinel node procedures}

\subsubsection{Benefit of sentinel node procedures}

Because of the lack of studies on the benefits of sentinel node procedures in vaginal cancer, the use of these procedures in vaginal cancer is still experimental. Studies of adjacent primary tumors of the uterine cervix and vulva provide some positive evidence for the use of sentinel node procedures in vaginal cancer. The flow chart in $>$ Fig. 1 shows the conventional and the experimental sequence for diagnosis and treatment; the sequence to be followed is described in Chapter 9.6.

\subsubsection{Lymph node mapping using sentinel lymph node technique}

\section{Consensus-based Statement 9.S15}

Expert consensus

Strength of consensus +++

Sentinel lymph node mapping and tracing the lymphatic drainage pathway in cases with vaginal cancer is the precondition for carrying out SLNB and for planning any subsequent surgical and/or radiotherapeutic treatment.

\section{Consensus-based Recommendation 9.E25}

\begin{tabular}{|l|l}
\hline Expert consensus & Strength of consensus +++
\end{tabular}

The following preconditions must be adhered to when using the sentinel lymph node technique in cases with vaginal cancer:

- No clinically suspicious lymph nodes and/or nodes suspicious on imaging.

- The diameter of the primary tumor is no larger than $4 \mathrm{~cm}$ in the vaginal plane and the tumor has not infiltrated any structures beyond the vagina (FIGOI).

- The patient has not undergone any prior operations in the lymphatic drainage area to be treated.

- Imaging is done using ${ }^{99} \mathrm{~m}$ technetium nanocolloid.

- A gamma probe must be used during surgical LN exploration; patent blue or - particularly when carrying out laparoscopic exploration indocyanine green (ICG) may also be used for staining.

- All resected sentinel LNs negative on $\mathrm{H} \&$ E staining are subjected to pathologic ultrastaging with immunohistochemistry.

- Those inguinal and pelvic lymphatic drainage areas not mapped using the sentinel LN technique are systematically explored surgically or included in the primary therapy (systematic LNE or RCTX).

\subsubsection{Validity of sentinel lymph node biopsy}

\section{Consensus-based Recommendation 9.E26}

\section{Expert consensus}

Strength of consensus +++

The sentinel lymph node technique may be used if the patient has consented after being informed in detail about the limited validity of the method in vaginal cancer because of the current lack of data. 


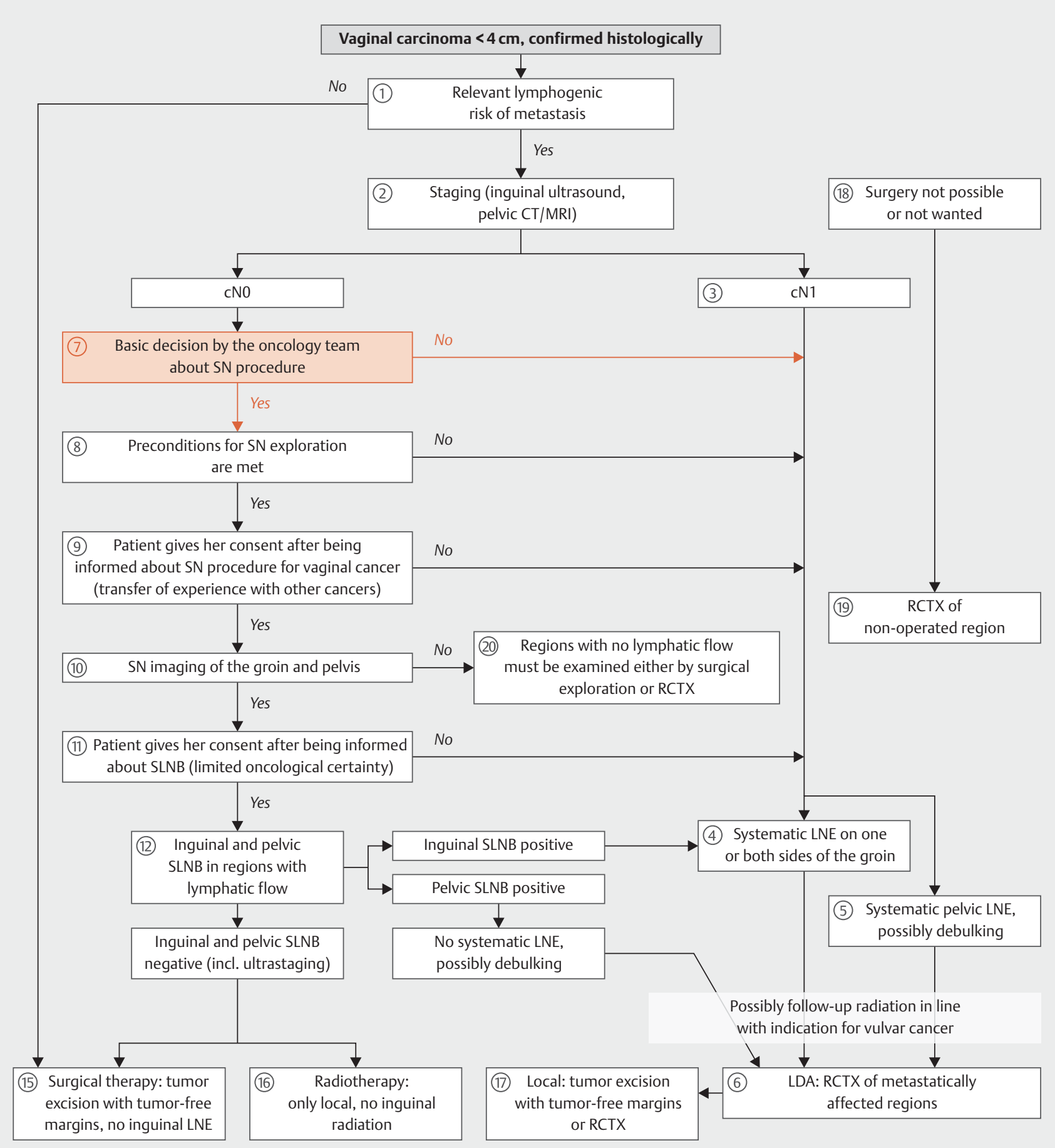

- Fig. 1 Flowchart for the diagnostic workup and treatment of vaginal carcinoma with the option of carrying out a sentinel LN procedure or not. [rerif]

\section{Consensus-based Statement 9.S16}

\section{Expert consensus}

\section{Strength of consensus +++}

Because of the rarity of these tumors, no valid data on the diagnostic certainty of SLNB in vaginal cancer will be available in the foreseeable future.
Systematic inguinofemoral or pelvic lymphadenectomy or radio (chemo)therapy of the respective areas probably offers greater oncological safety but patients will have to accept a higher rate of side effects.

To evaluate the usefulness of sentinel lymph node biopsy in vaginal cancer, a new central register has been set up to collect treatment data and the course of disease of all patients with vagi- 
nal cancer in Germany ("knowledge-generating healthcare research" by the DKG). This national interdisciplinary vaginal carcinoma register is supported by the medical societies DGGG, AGO and DEGRO. All cases of vaginal cancer must be reported to the Radiotherapy Department of Cologne University (email: martina. illig@uk-koeln.de). All hospitals with a tumor board which discusses and treats cases of vaginal carcinoma are requested to contact the registration office.

\subsubsection{Planning primary radio(chemo)therapy}

\section{Consensus-based Recommendation 9.E27}

\section{Expert consensus}

Strength of consensus +++

If SLN imaging is carried out preoperatively followed by intraoperative SLN biopsy, the findings should be taken into consideration when planning the radiation fields for primary radiotherapy.

Please refer to this chapter in the long version of the guideline to read how staging results from sentinel lymph node procedures can improve the situation.

\subsection{Diagnosis and therapy with and without sentinel lymph node procedures}

\subsubsection{Process description of diagnostic workup and treatment}

This chapter describes the recommended treatment approach for primary vaginal carcinoma with and without a sentinel lymph node procedure; the circled numbers correspond to the respective steps shown in $\mathbf{F}$ Fig. 1.

\subsection{Systematic lymphanedectomy}

Lymphatic drainage areas relevant for vaginal cancer include the pelvic, anorectal and inguinofemoral lymph nodes. In addition to these LNs, very advanced lymphogenic metastatic vaginal cancer may also affect the paraaortic LNs. As with SLN procedures, pretherapeutic systematic LNE in the above-mentioned lymphatic drainage areas may be useful to determine the extent of the required radiation for subsequent primary radio(chemo)therapy based on staging findings. Lymph node regions shown to have no metastatic involvement should not be irradiated.

If metastatic involvement is found to be present in pelvic lymph nodes on one side, it is important to ensure that both sides are treated with radiotherapy in accordance with the uniform approach used to treat pelvic lymph node metastasis from other primary tumors (carcinomas of the uterine cervix, prostate, endometrium, rectum, and anus), There are no data available on hemipelvis radiotherapy for vaginal cancer.

\subsection{Surgical tumor reduction (debulking) prior to radio(chemo)therapy}

In cases with advanced vaginal carcinoma and large circumscribed lymph node metastases in the groin or pelvis, the option to carry out preparatory surgical debulking as a means of improving the response to radio(chemo)therapy should be considered. The overall oncological situation, the patient's general operability, and lo- cal resectability as well as the expected morbidity following therapy must all be taken into consideration.

\section{Consensus-based Recommendation 9.E28 \\ Expert consensus \\ Strength of consensus +++}

Treatment planning for vaginal carcinoma should be based on the flowchart showing the diagnostic workup and treatment of vaginal carcinoma ( Fig. 1).

\section{0}

10.1

\section{Radio(chemo)therapy for vaginal carcinoma}

Radiotherapy alone has been used since many decades to treat both local and advanced squamous cell carcinoma and adenocarcinoma of the vagina.

Depending on the tumor stage, radiotherapy alone can achieve high local control rates, ranging from $85-95 \%$ for FIGO stage I, to $70-80 \%$ for FIGO stage II and around $50-70 \%$ for FIGO stages IIIIVA [27-31].

Please refer to this chapter in the long version of the guideline for details on the dose-response relationship, the different radiotherapy techniques and the target volume definitions.

\subsection{Radiotherapy of the tumor region}

A second resection should be considered if the tumor was not resected in its entirety. If this is not feasible or if the expected functional results of this second resection are expected to be unsatisfactory, then local radiotherapy should be administered to improve local control.

\section{Consensus-based Recommendation 10.E29}

Expert consensus Strength of consensus +++

In primary radio(chemo)therapy, the target volume should cover the primary tumor including the safety margin with a dose of $>70 \mathrm{~Gy}$.

\section{Consensus-based Statement 10.S17}

Expert consensus

Strength of consensus +++

There is no evidence which specifies a minimal histological safety margin between the tumor and the edge of the resected specimen nor that resection margins below such a minimal histological safety margin represent an indication for administering radiotherapy to the tumor region postoperatively.

Consensus-based Recommendation 10.E30 


\subsection{Radiotherapy of the lymphatic drainage pathways}

\subsubsection{Inguinal lymph nodes}

If inguinal lymph node metastasis has been confirmed histologically, the recommendations to administer postoperative radiotherapy will be based on the recommendations used to treat vulvar cancer. Radiotherapy planning should opt for modern proton therapy in preference to electron therapy.

\subsubsection{Pelvic lymph nodes}

Radiotherapy with bilateral radiation of the pelvic lymph drainage pathways is recommended if pelvic lymph node metastasis has been confirmed histologically. Even if metastasis is only confirmed on one side, radiotherapy should always be administered to both sides.

\subsection{Radio(chemo)therapy}

\section{Consensus-based Recommendation 10.E31}

\section{Expert consensus} Strength of consensus +++

Primary radiotherapy should also be offered in the form of simultaneous radiochemotherapy.

\section{Consensus-based Recommendation 10.E32}

The inguinofemoral and pelvic lymphatic drainage areas on both sides should also be irradiated if surgical lymph node staging was indicated but surgical staging was not carried out.

\section{Consensus-based Recommendation 10.E33}

\section{Expert consensus}

Strength of consensus +++

The patient's comorbidities, own wishes, and clinical situation need to be considered before administering cisplatin \pm 5 - FU or mitomycin \pm 5 - FU.

\section{Consensus-based Statement 10.518}

\section{Expert consensus}

Strength of consensus +++

In primary radiotherapy, achieving sufficiently high tumor doses is decisive for the success of therapy. Brachytherapy, possibly in combination with percutaneous radiotherapy, plays an important role in this context.

\section{Consensus-based Recommendation 10.E34}

\section{Expert consensus}

Strength of consensus +++

As with vulvar cancer, adjuvant radio(chemo)therapy after $\mathrm{R} 1 / \mathrm{R} 2$ resection should be administered to the tumor area and the affected groin area if inguinal metastasis is present and bilaterally if there is pelvic metastasis.
The recommendation to administer simultaneous radiochemotherapy to treat vaginal cancer is a transfer of the experience with this approach in other tumors. Because of the rarity of vaginal carcinoma, we recommend that vaginal cancer should be treated in centers which deal with larger numbers of patients [32-34].

10.9 Side effects of therapy, their prophylaxis and treatment

\subsubsection{Late radiogenic side effects}

Please refer to this chapter in the long version of the guideline for details on therapy-related toxicity, the choice of radiation technique and its impact on toxicity.

Symptomatic measures such as treatment for diarrhea, sitz baths, vaginal douching and the intravaginal application of a topical ointment (poss. using a tampon) to prevent adhesions are useful. Acute reactions are common but usually heal after the end of radiotherapy with no further effects. Important prophylactic measures against chronic consequences of scarring such as vaginal stenosis include the above-listed therapies applied consistently to treat acute reactions and the early and regular use of vaginal dilators, particularly in young and sexually active patients [35-37, 38].

\subsubsection{Preservation of ovarian function and/or fertility}

Young patients should be informed about the possibility of preserving ovarian function using ovariopexy with clip marking and the use of the latest radio-oncology techniques [39-43]. Please consult the German-language AWMF S2k guideline "Fertilitätserhalt bei onkologischen Erkrankungen" on preserving fertility in patients with oncologic disease for more information about indications and techniques [44]

\section{Systemic therapy}

The current data on the use of systemic therapy to treat vaginal cancer is based on single case reports and small series which were analyzed retrospectively. Most therapeutic concepts were adapted from the treatment concepts used for cervical cancer.

\subsection{Neoadjuvant chemotherapy}

\section{Consensus-based Statement 11.S19}

Expert consensus

Strength of consensus +++

The use of neoadjuvant chemotherapy to treat vaginal cancer is currently still an experimental concept.

\subsection{Radio(chemo)therapy}

\section{Consensus-based Statement 11.S20}

\begin{tabular}{l|l}
\hline Expert consensus & Strength of consensus +++
\end{tabular}

Using radio(chemo)therapy to treat vaginal cancer is analogous to using radio(chemo)therapy to treat cervical and vulvar cancer. 


$$
\begin{aligned}
& \text { Chemotherapy in the palliative setting } \\
& \text { (recurrence, secondary metastasis, } \\
& \text { primary metastasizing vaginal carcinoma) }
\end{aligned}
$$

The references for the few available reports and studies on vaginal cancer are given in the long version of the guideline.

For the general chapters 12 Supportive Therapy, 13 Psychooncology and Quality of Life, 14 Rehabilitation and 15 Integrative Medicine, please refer to the long version of the guideline on the homepage of the AWMF: https://www.awmf.org/leitlinien /detail/II/032-042.html

\section{6}

\begin{tabular}{|c|c|c|c|}
\hline \multicolumn{4}{|c|}{ Consensus-based Recommendation 16.E36 } \\
\hline \multicolumn{2}{|l|}{ Expert consensus } & \multicolumn{2}{|c|}{$\begin{array}{l}\text { Strength of consensus } \\
+++\end{array}$} \\
\hline \multicolumn{4}{|c|}{$\begin{array}{l}\text { Follow-up care of vaginal cancer should include the following routine } \\
\text { examinations: }\end{array}$} \\
\hline Examination & $\begin{array}{l}1 \text { st-3rd } \\
\text { year }\end{array}$ & $\begin{array}{l}\text { 4th-5th } \\
\text { year }\end{array}$ & $\begin{array}{l}\text { From } \\
\text { 6th year }\end{array}$ \\
\hline Medical history & $\begin{array}{l}\text { every } \\
3 \text { months }\end{array}$ & $\begin{array}{l}\text { every } \\
6 \text { months }\end{array}$ & annually \\
\hline Clinical examination & $\begin{array}{l}\text { every } \\
3 \text { months }\end{array}$ & $\begin{array}{l}\text { every } \\
6 \text { months }\end{array}$ & annually \\
\hline $\begin{array}{l}\text { Speculum examination, } \\
\text { colposcopy (cervix/vagina/ } \\
\text { vulva/anus), cytology }\end{array}$ & $\begin{array}{l}\text { every } \\
3 \text { months }\end{array}$ & $\begin{array}{l}\text { every } \\
6 \text { months }\end{array}$ & annually \\
\hline \multicolumn{4}{|c|}{$\begin{array}{l}\text { References: Adapted from Salani R et al. } 2011 \text { [45], Dannecker C et al. } 2016 \\
\text { [46], Oonk MH et al. } 2003 \text { [47] }\end{array}$} \\
\hline
\end{tabular}

\section{Follow-up}

\begin{tabular}{|l|l|}
\hline Consensus-based Recommendation $16 . E 35$ \\
\hline Expert consensus & Strength of consensus +++ \\
\hline Patients who were treated for vaginal HSIL should have regular risk-adapted \\
follow-up appointments for the rest of their lives.
\end{tabular}

The long version of this guideline includes additional information on the clinical follow-up, the short and long-term impact of the disease and its therapy, and the effects of lifestyle choices and psychosexual and psychosocial follow-up care.

\section{Therapy for locoregional recurrence and distant metastasis}

Around $90 \%$ of recurrences occur within the first five years $[8,48$, 49]. About $25 \%$ of all recurrences are local or locoregional [48].

A palliative concept is used to treat distant metastasis; it is important to exclude any distant metastasis before deciding on the appropriate therapy to treat locoregional recurrence.

\subsection{Diagnostic workup}

The following diagnostic workup should be carried out if there is a suspicion of locoregional recurrence:

- gynecological examination and histological examination

- vaginal ultrasound imaging

- pelvic MRI [48]

- cystoscopy and rectoscopy, exclusion of fistula

- CT scan of the thorax and abdomen to exclude distant metastasis

It should be noted in this context that it is not uncommon for primary therapy to create long-term complications which can mimic recurrence, particularly fistula formation [49].

\subsection{Treatment of locoregional recurrence}

\section{Consensus-based Statement 17.S21}

Expert consensus

Strength of consensus +++

The decision to treat local or locoregional recurrence depends on the previous therapy, the extent of recurrence, and the patient's general condition. The decision is made an individual basis; treatment options include surgery, radiotherapy, radio(chemo)therapy and best supportive care.

\section{Consensus-based Recommendation 17.E37}

\section{Expert consensus}

Strength of consensus +++

The decision about the appropriate treatment approach for a patient with local or locoregional recurrence must be made by an interdisciplinary tumor board.

The long version of the guideline has drafted some cornerstones for treating recurrence which must be followed. The limited options to treat distant metastasis are explained in the long version.

To read the general chapter 18 Palliative Medical Care, please refer to the long version on the homepage of the AWMF: https:// www.awmf.org/leitlinien/detail/II/032-042.html

\section{Conflict of Interest}

The conflicts of interests of the authors are listed in the long version of the guideline. 


\section{References}

[1] Schubert-Fritschle G, Schlesinger-Raab A, Engel J. Malignome der Vulva und Vagina. In: Dannecker C, Kolben M, Kürzl R, Hrsg. Manuale Tumorzentrum München. 2. Aufl. München: Zuckschwerdt Verlag; 2011

[2] Lilic V, Lilic G, Filipovic $S$ et al. Primary carcinoma of the vagina. J BUON 2010; 15: 241-247

[3] Melnick S, Cole P, Anderson D et al. Rates and risks of diethylstilbestrolrelated clear-cell adenocarcinoma of the vagina and cervix. An update. N Engl J Med 1987; 316: 514-516

[4] Ries LAG, Young JL, Keel GE, Eisner MP, Lin YD, Horner MJ, eds. SEER Survival Monograph: Cancer Survival among Adults: U.S. SEER Program, 1988-2001, Patient and Tumor Characteristics. National Cancer Institute, SEER Program, NIH Pub. No. 07-6215, Bethesda, MD: NIH; 2007

[5] Madsen BS, Jensen HL, van den Brule AJ et al. Risk factors for invasive squamous cell carcinoma of the vulva and vagina-population-based case-control study in Denmark. Int J Cancer 2008; 122: 2827-2834

[6] Henson D, Tarone R. An epidemiologic study of cancer of the cervix, vagina, and vulva based on the Third National Cancer Survey in the United States. Am J Obstet Gynecol 1977; 129: 525-532

[7] Aho M, Vesterinen E, Meyer B et al. Natural history of vaginal intraepithelial neoplasia. Cancer 1991; 68: 195-197

[8] Gadducci A, Fabrini MG, Lanfredini $\mathrm{N}$ et al. Squamous cell carcinoma of the vagina: natural history, treatment modalities and prognostic factors. Crit Rev Oncol Hematol 2015; 93: 211-224

[9] Strander B, Andersson-Ellstrom A, Milsom I et al. Long term risk of invasive cancer after treatment for cervical intraepithelial neoplasia grade 3 : population based cohort study. BMJ 2007; 335: 1077

[10] Horn LC, Schierle K. Pathologie der Präkanzerosen und der Karzinome von Vulva und Vagina sowie morphologische Prognosefaktoren. Onkologe 2009; 15: 15-27

[11] Ferenzcy AS, Colgan T], Herrington CS, Hirschowitz L, Löning T, Park KJ, Stoler M, Wells M, Wilbur DC, Wright T. Epithelial Tumors of the Vagina. In: Kurman RJ, Carcangiu ML, Herrington CS, Young RH, eds. WHO Classification of Tumours of the female reproductive Tract. Lyon: IARC Press; 2014: $210-217$

[12] Horn LC, Schierle K, Schmidt D et al. [Current TNM/FIGO classification for cervical and endometrial cancer as well as malignant mixed mullerian tumors. Facts and background]. Pathologe 2011; 32: 239-243

[13] Darragh TM, Colgan T], Thomas Cox J et al. The Lower Anogenital Squamous Terminology Standardization project for HPV-associated lesions: background and consensus recommendations from the College of American Pathologists and the American Society for Colposcopy and Cervical Pathology. Int J Gynecol Pathol 2013; 32: 76-115

[14] Wittekind C. TNM-Klassifikation maligner Tumoren. 8th ed. Weinheim: Wiley-VHC; 2017: 213-215

[15] Adams TS, Cuello MA. Cancer of the vagina. Int J Gynaecol Obstet 2018; 143 (Suppl. 2): 14-21

[16] Wu X, Matanoski G, Chen VW et al. Descriptive epidemiology of vaginal cancer incidence and survival by race, ethnicity, and age in the United States. Cancer 2008; 113: 2873-2882

[17] Kurman RJ, Ronnett BM, Sherman ME, Wilkinson EJ. Tumors of the Vagina. Tumors of the Cervix, Vagina and Vulva. In: Kurman RJ, Ronnett BM, Sherman ME, Wilkinson EJ, eds. AFIP Atlas of Tumor Pathology, Series 4. Silver Spring: ARP Press; 2010: 255-291

[18] Wilkinson EJ, Rico MJ, Pierson KK. Microinvasive carcinoma of the vulva. Int J Gynecol Pathol 1982; 1: 29-39

[19] Crum CP, Herrington CS, McCluggage WG, Regauer S, Wilkinson EJ. Epithelial Tumors of the Vulva. In: Kurman RJ, Carcangiu ML, Herrington CS, Young RH, eds. WHO Classification of Tumours of the female reproductive Tract. Lynon: IARC Press; 2014: 233-242
[20] Hermanek P, Hutter RV, Sobin LH et al. International Union Against Cancer. Classification of isolated tumor cells and micrometastasis. Cancer 1999; 86: 2668-2673

[21] Wittekind C, Compton C, Brirley J, Sobin L. TNM Supplement: a Commentary on Uniform Use. London: Wiley-Blackwell; 2012

[22] American Joint Committee on Cancer. Vagina. In: Amin MB, Edge $S$, Greene F et al., eds. AJCC Cancer Staging Manual. 8th ed. New York: Spinger; 2017: 641-647

[23] Luo LM, Huang HF, Pan LY et al. [Clinical analysis of 42 cases of primary malignant tumor in vagina]. Zhonghua Fu Chan Ke Za Zhi 2008; 43: 923-927

[24] Stock RG, Chen AS, Seski J. A 30-year experience in the management of primary carcinoma of the vagina: analysis of prognostic factors and treatment modalities. Gynecol Oncol 1995; 56: 45-52

[25] Manetta A, Gutrecht EL, Berman ML et al. Primary invasive carcinoma of the vagina. Obstet Gynecol 1990; 76: 639-642

[26] Tjalma WA, Monaghan JM, de Barros Lopes A et al. The role of surgery in invasive squamous carcinoma of the vagina. Gynecol Oncol 2001; 81: 360-365

[27] Frank S], Jhingran A, Levenback $C$ et al. Definitive radiation therapy for squamous cell carcinoma of the vagina. Int J Radiat Oncol Biol Phys 2005; 62: 138-147

[28] de Crevoisier R, Sanfilippo N, Gerbaulet A et al. Exclusive radiotherapy for primary squamous cell carcinoma of the vagina. Radiother Oncol 2007; 85: $362-370$

[29] Greenwalt JC, Amdur RJ, Morris CG et al. Outcomes of Definitive Radiation Therapy for Primary Vaginal Carcinoma. Am J Clin Oncol 2015; 38: 583-587

[30] Lian ], Dundas G, Carlone M et al. Twenty-year review of radiotherapy for vaginal cancer: an institutional experience. Gynecol Oncol 2008; 111: 298-306

[31] Jang WI, Wu HG, Ha SW et al. Definitive radiotherapy for treatment of primary vaginal cancer: effectiveness and prognostic factors. Int J Gynecol Cancer 2012; 22: 521-527

[32] Smith GL, Jiang J, Giordano SH et al. Trends in the Quality of Treatment for Patients With Intact Cervical Cancer in the United States, 1999 Through 2011. Int J Radiat Oncol 2015; 92: 260-267

[33] Showalter TN, Camacho F, Cantrell LA et al. Determinants of Quality Care and Mortality for Patients With Locally Advanced Cervical Cancer in Virginia. Medicine (Baltimore) 2016; 95: e2913

[34] Lin JF, Berger JL, Krivak TC et al. Impact of facility volume on therapy and survival for locally advanced cervical cancer. Gynecol Oncol 2014; 132: $416-422$

[35] Bakker RM, ter Kuile MM, Vermeer WM et al. Sexual rehabilitation after pelvic radiotherapy and vaginal dilator use: consensus using the Delphi method. Int ] Gynecol Cancer 2014; 24: 1499-1506

[36] Bakker RM, Mens JW, de Groot HE et al. A nurse-led sexual rehabilitation intervention after radiotherapy for gynecological cancer. Support Care Cancer 2016. doi:10.1007/s00520-016-3453-2

[37] Bakker RM, Vermeer WM, Creutzberg CL et al. Qualitative accounts of patients' determinants of vaginal dilator use after pelvic radiotherapy. J Sex Med 2015; 12: 764-773

[38] Lethaby A, Ayeleke RO, Roberts H. Local oestrogen for vaginal atrophy in postmenopausal women. Cochrane Database Syst Rev 2016; (8): CD001500. doi:10.1002/14651858.CD001500.pub3

[39] Perri T, Ben-Baruch G, Davidson T et al. Use of Titanium Spiral Tacks for Long-term Oophoropexy Before Pelvic Irradiation. Int J Gynecol Cancer 2014; $24: 1133-1136$

[40] Han SS, Kim YH, Lee SH et al. Underuse of ovarian transposition in reproductive-aged cancer patients treated by primary or adjuvant pelvic irradiation. J Obstet Gynaecol Res 2011; 37: 825-829 
[41] Morice P, Castaigne D, Haie-Meder C et al. Laparoscopic ovarian transposition for pelvic malignancies: indications and functional outcomes. Fertil Steril 1998; 70: 956-960

[42] Meirow D, Nugent D. The effects of radiotherapy and chemotherapy on female reproduction. Hum Reprod Update 2001; 7: 535-543

[43] Ghadjar P, Budach V, Kohler C et al. Modern radiation therapy and potential fertility preservation strategies in patients with cervical cancer undergoing chemoradiation. Radiat Oncol 2015; 10: 50

[44] DGGG; DGU; BGRM. Fertility preservation for patients with malignant disease. Guideline of the DGGG, DRU and BGRM (S2k - Level, AWMF Registry No.015/082, November 2017). 2017. Online: http://www. ammf.org/leitlinien/detail/I/015-082.html; last access: 15.02.2018
[45] Salani R, Backes FJ, Fung MF et al. Posttreatment surveillance and diagnosis of recurrence in women with gynecologic malignancies: Society of Gynecologic Oncologists recommendations. Am J Obstet Gynecol 2011; 204: $466-478$

[46] Dannecker C, Strand V, Hegewisch-Becker S. Nachsorge beim Vulva- und Vaginalkarzinom. Der Onkologe 2014; 20: 355-357

[47] Oonk MH, de Hullu JA, Hollema $\mathrm{H}$ et al. The value of routine follow-up in patients treated for carcinoma of the vulva. Cancer 2003; 98: 26242629

[48] Gardner CS, Sunil ], Klopp AH et al. Primary vaginal cancer: role of MRI in diagnosis, staging and treatment. Br J Radiol 2015; 88: 20150033

[49] Gunderson CC, Nugent EK, Yunker AC et al. Vaginal cancer: the experience from 2 large academic centers during a 15-year period. J Low Genit Tract Dis 2013; 17: 409-413 


\section{Guideline Program}

\section{Editors}

Leading Professional Medical Associations

\section{OJ}

\section{OEGGE}

\section{German Society of Gynecology and Obstetrics} (Deutsche Gesellschaft für Gynäkologie und Geburtshilfe e. V. [DGGG])

Head Office of DGGG and Professional Societies Hausvogteiplatz 12, DE-10117 Berlin info@dggg.de

http://www.dggg.de/

\section{President of DGGG}

Prof. Dr. med. Anton Scharl

Direktor der Frauenkliniken

Klinikum St. Marien Amberg

Mariahilfbergweg 7, DE-92224 Amberg

Kliniken Nordoberpfalz AG

Söllnerstraße 16, DE-92637 Weiden

\section{DGGG Guidelines Representatives}

Prof. Dr. med. Matthias W. Beckmann Universitätsklinikum Erlangen, Frauenklinik Universitätsstraße 21-23, DE-91054 Erlangen

Prof. Dr. med. Erich-Franz Solomayer Universitätsklinikum des Saarlandes Geburtshilfe und Reproduktionsmedizin Kirrberger Straße, Gebäude 9, DE-66421 Homburg

\section{Guidelines Coordination}

Dr. med. Paul Gaß, Dr. med. Gregor Olmes, Christina Meixner Universitätsklinikum Erlangen, Frauenklinik Universitätsstraße 21-23, DE-91054 Erlangen fk-dggg-leitlinien@uk-erlangen.de http://www.dggg.de/leitlinienstellungnahmen
Austrian Society of Gynecology and Obstetrics (Österreichische Gesellschaft für Gynäkologie und Geburtshilfe [OEGGG])

Frankgasse 8, AT-1090 Wien stephanie.leutgeb@oeggg.at http://www.oeggg.at

\section{President of OEGGG}

Prof. Dr. med. Petra Kohlberger

Universitätsklinik für Frauenheilkunde Wien

Währinger Gürtel 18-20, AT-1090 Wien

\section{OEGGG Guidelines Representatives}

Prof. Dr. med. Karl Tamussino

Universitätsklinik für Frauenheilkunde und Geburtshilfe Graz Auenbruggerplatz 14, AT-8036 Graz

Prof. Dr. med. Hanns Helmer Universitätsklinik für Frauenheilkunde Wien Währinger Gürtel 18-20, AT-1090 Wien

\section{gynécologie}

Swiss Society of Gynecology and Obstetrics (Schweizerische Gesellschaft für Gynäkologie und Geburtshilfe [SGGG])

Gynécologie Suisse SGGG Altenbergstraße 29, Postfach 6, CH-3000 Bern 8

sekretariat@sggg.ch

http://www.sggg.ch/

President of SGGG

Dr. med. Irène Dingeldein

Längmatt 32, CH-3280 Murten

SGGG Guidelines Representatives

Prof. Dr. med. Daniel Surbek

Universitätsklinik für Frauenheilkunde

Geburtshilfe und feto-maternale Medizin

Inselspital Bern

Effingerstraße 102, CH-3010 Bern

Prof. Dr. med. René Hornung

Kantonsspital St. Gallen, Frauenklinik

Rorschacher Straße 95, CH-9007 St. Gallen 